\title{
Thalamic deep brain stimulation for tremor among multiple sclerosis patients
}

\section{Głęboka stymulacja wzgórza w leczeniu drżenia w przebiegu stwardnienia rozsianego}

\author{
Tomasz Mandat', Henryk Koziara', Marcin Tutai, ${ }^{23}$, Rafał Rola ${ }^{4}$, Wiestaw Bonicki', Paweł Nauman ${ }^{5}$ \\ ${ }^{1}$ Klinika Nowotworów Układu Nerwowego, Centrum Onkologii - Instyłut im. Marii Skłodowskiej-Curie w Warszawie \\ 20ddział Kliniczny Kliniki Neurologii, Szpital Uniwersytecki w Krakowie \\ 3 Medtronic Poland \\ 4I Klinika Neurologii, Instytut Psychiatrii i Neurologii w Warszawie \\ ${ }^{5}$ Klinika Neurochirurgii, Instytut Psychiatrii i Neurologii w Warszawie
}

Neurologia i Neurochirurgia Polska 2010; 44, 6: 542-545

\begin{abstract}
Background and purpose: Disabling tremor might be the main cause of disability of multiple sclerosis (MS) patients. Neuromodulation with deep brain stimulation of the thalamic nucleus ventralis intermedius (Vim DBS) is a well accepted method of neurosurgical treatment of tremor related to essential tremor or Parkinson disease. Vim DBS is not widely used to control MS tremor.
\end{abstract}

Material and methods: Five MS patients with tremor (3 females and 2 males) were treated with Vim DBS. Age at implantation was $37 \pm 5$ years. MS lasted from 5 to 12 years (mean 6) and tremor was the main cause of disability of those patients from 2 to 5 years (mean 3 ) before surgery. Clinical condition of the group was evaluated with spirography, the modified Fahn scale and the modified Activity of Daily Living (ADL) scale. Evaluations were performed before surgery and 3 months after surgery. MRI exclusion criteria were the presence of a thalamic hyperintense signal in $\mathrm{T} 2$-weighted images or ventricular enlargement. The procedures of implantation were performed under local and general anaesthesia.

Results: Intensity of contralateral limb tremor during intraoperative macrostimulation was reduced in the whole group. The therapeutic effect of DBS was maintained at three-month follow-up. Mean contralateral limb tremor reduction was $40 \%$. Mean ADL score improved by $18 \%$. No mortality or morbidity was reported in the group.

\section{Streszczenie}

Wstęp i cel pracy: Znacznie nasilone drżenie może być główną przyczyną inwalidztwa chorych na stwardnienie rozsiane (SR). Neuromodulacja z zastosowaniem głębokiej stymulacji mózgu (deep brain stimulation - DBS) jądra brzuszno-pośredniego wzgórza (Vim) jest zaakceptowaną metodą leczenia neurochirurgicznego drżenia w przebiegu drżenia samoistnego oraz drżenia w chorobie Parkinsona. Wykorzystanie Vim DBS w leczeniu drżenia u chorych na SR wciąż nie jest powszechne.

Materiał i metody: Pięciu chorych (3 kobiety i 2 mężczyzn) leczono metodą Vim DBS z powodu drżenia w przebiegu SR. Wiek chorych w chwili wszczepienia stymulatora wynosił $37 \pm 5$ lat. Objawy SR pojawiły się na 5 do 12 lat (średnio 6 lat) przed kwalifikacją do zabiegu operacyjnego, a znacznie nasilone drżenie było główną przyczyną inwalidztwa u tych chorych od 2 do 5 lat (średnio 3 lata) przed kwalifikacją. Nasilenie drżenia oceniano z wykorzystaniem spirografii, zmodyfikowanej skali Fahna oraz zmodyfikowanej skali oceny podstawowych czynności życiowych (activities of daily living - ADL). Badania przeprowadzano przed zabiegiem operacyjnym oraz 3 miesiące po zabiegu. Pacjenci ze stwierdzanymi w MRI hiperintensywnymi zmianami T2 we wzgórzu oraz poszerzeniem układu komorowego nie byli kwalifikowani do leczenia operacyjnego. Zabieg wszczepienia stymulatora przeprowadzano w znieczuleniu miejscowym i ogólnym.

Correspondence address: dr Tomasz Mandat, Klinika Nowotworów Układu Nerwowego, Centrum Onkologii - Instyłut im. Marii Skłodowskiej-Curie, ul. Roentgena 5, 02-781 Warszawa, e-mail: tomaszmandat@yahoo.com Received: 27.04.2010; accepted: 20.09.2010 
Conclusions: The study confirms the value and safety of Vim DBS for treatment of MS-related tremor. Further study on a larger population and introduction of a qualification protocol might increase efficacy of the treatment.

Key words: multiple sclerosis, tremor, deep brain stimulation.

\section{Introduction}

A large group of multiple sclerosis (MS) patients suffers from medically refractory severe tremor. If the tremor is responsible for the patient's disability, surgical treatment might be an option. The complex neurological syndrome of MS and relapsing and remitting character of the disease result in unclear incidence and prevalence of disabling tremor among MS patients [1-5]. The efficacy of thalamotomy and of deep brain stimulation of the thalamic nucleus ventralis intermedius (Vim DBS) are comparable. The higher complication rate of thalamotomy favours Vim DBS, especially if the procedure is performed bilaterally. Numerous studies have been undertaken to evaluate efficacy and to standardize the protocol for treatment of MS-related tremor but no consensus has been reached. Differentiation of tremor and cerebellar ataxia might play the key role in successful treatment $[1,2,6-19]$. The authors present a group of patients treated with Vim DBS for MS-related tremor.

\section{Material and methods}

Five MS patients with tremor, including 3 females and 2 males, were qualified for Vim DBS. Consent forms were signed by patients and their caregivers. Mean age at implantation was $37 \pm 5$ years. MS lasted from 5 to 12 years (mean 6 years). As reported, tremor remained the main cause of patients' disability from 2 to 5 years (mean 3 years). Clinical condition of the group was evaluated with spirography, the modified Fahn scale and the modified Activity of Daily Living (ADL) scale [19-22]. Treatment was restricted to patients with secondary pro-
Wyniki: Śródoperacyjnie obserwowano zmniejszenie nasilenia drżenia u wszystkich chorych. Efekt stymulacji utrzymywał się w trzymiesięcznej obserwacji. Średnie zmniejszenie nasilenia drżenia w badanej grupie oceniano na $40 \%$. Wyniki uzyskane w skali ADL uległy poprawie o $18 \%$. Nie stwierdzano powikłań leczenia w badanej grupie.

Wnioski: Przedstawione wyniki leczenia drżenia u chorych na SR potwierdzają bezpieczeństwo oraz skuteczność Vim DBS. Zwiększenie grupy chorych leczonych tą metodą oraz wprowadzenie protokołu kwalifikacyjnego może zwiększyć skuteczność omawianej terapii.

Słowa kluczowe: stwardnienie rozsiane, drżenie, głęboka stymulacja mózgu.

gressive MS, without superimposed relapses prior to surgery. To be qualified for the surgery, patients had to have a history of pharmacologically resistant upper extremity tremor that lasted unchanged for at least six months. The patients were excluded from the study if the upper extremity motor strength was less than $4 / 5$. MRI exclusion criteria were the presence of thalamic hyperintense signal in T2-weighted images and ventricular enlargement (hydrocephalus ex vacuo). The implantations were performed under local and general anaesthesia. The target point was identified with the indirect method followed by microrecording and macrostimulation [23-25]. When the target was identified, permanent electrodes were implanted under fluoroscopic guidance. The DBS was initiated on the first day following surgery. Initial parameters of the monopolar stimulation were set at the frequency of $130 \mathrm{~Hz}$ with pulse width of $90 \mu$ s and mean amplitude of $2 \mathrm{~V}$. The parameters were readjusted over time according to the clinical effects. If needed, the stimulation parameters were changed to bipolar, the frequency was increased up to $185 \mathrm{~Hz}$, pulse width was increased up to $180 \mu$ s and the amplitude was increased up to $3.6 \mathrm{~V}$. Evaluations were performed before surgery and 3 months after surgery. All of the preoperative and postoperative tests were video recorded to allow subsequent double-blinded evaluation.

\section{Results}

Intensity of contralateral limb tremor was reduced intraoperatively within the whole group. Reduction of tremor after initialization of the stimulation was reported in the whole group as well. At 3-month follow-up, mean upper limb tremor reduction was $40 \%$ on the 
5 -grade Fahn scale. In spirography, tremor was reduced by $5-75 \%$. Mean ADL score improved by $18 \%$ (Table 1 ). No mortality or morbidity related to the surgery or stimulation itself was reported within the group.

\section{Discussion}

Tremor is recognized as a poor prognostic factor for MS patients. The prevalence of tremor among MS patients is estimated at $32 \%$, and it is recognized to be the main cause of disability among $6 \%$ of them. Even though 40 years have passed since Cooper reported a positive effect of DBS on MS tremor, no qualification protocol has been developed yet. Lack of objective tools of MS tremor evaluation is one of many reasons why the consensus has not been established [1-5]. Poor results of conservative treatment force the introduction of invasive, neurosurgical therapy in treatment of MS-related tremor. The only effective surgical alternative of MS tremor treatment to Vim DBS is thalamotomy. The effi-

Table 1. Activities of Daily Living Scale* used for evaluation of efficacy in the group. Pre-surgical and post-surgical assessment as well as improvement in each task are listed

\begin{tabular}{|llccc|}
\hline No. Task & $\begin{array}{c}\text { Before } \\
\text { surgery }\end{array}$ & $\begin{array}{c}\text { After } \\
\text { surgery }\end{array}$ & $\begin{array}{c}\text { Improve- } \\
\text { ment }\end{array}$ \\
\hline 1. & Eating & 3 & 2.2 & $-27 \%$ \\
\hline 2. & Drinking & 2.8 & 1.8 & $-36 \%$ \\
\hline 3. & Pouring water & 2.6 & 1.8 & $-31 \%$ \\
\hline 4. & Brushing teeth & 2.8 & 2.0 & $-29 \%$ \\
\hline 5. & Face and hand hygiene & 2.8 & 1.8 & $-36 \%$ \\
\hline 6. & Taking bath or shower & 2.2 & 1.8 & $-18 \%$ \\
\hline 7. & Using toilet & 2.6 & 2.0 & $-23 \%$ \\
\hline 8. & Tying shoelaces & 3 & 3 & 0 \\
\hline 9. & Fastening buttons & 3 & 3 & 0 \\
\hline 10. & Handwriting & 3 & 2.6 & $-13 \%$ \\
\hline 11. & Book reading & 3 & 2.8 & $-7 \%$ \\
\hline 12. & Drawing by hand & 3 & 2.6 & $-13 \%$ \\
\hline 13. & Phone dialling & 3 & 2.6 & $-13 \%$ \\
\hline 14. & Sending letters & 3 & 2.8 & $-7 \%$ \\
\hline 15. & Locking doors with a key & 2.8 & 2.2 & $-21 \%$ \\
\hline & Total score (0-45) & 42.6 & 35 & $-18 \%$ \\
\hline
\end{tabular}

*0 - able to perform independently; 1 - able to perform with effort and some help, 2 - able to perform with excessive effort, 3 - unable to perform independently cacy of both methods in tremor reduction is similar, but irreversible adverse events that might appear after ablative procedures, especially if performed bilaterally, draw attention to the less invasive neuromodulatory method, Vim DBS. The ethical question of whether a lesion can or should be performed on a morphologically affected MS brain is another aspect highlighted by some authors $[1,4,6,8,10,11,15,18,19]$.

The aetiology of MS tremor is still not well understood. It is suspected that lesions in the cerebellum or cerebro-thalamic pathways are responsible for kinetic tremor, but complex morphological changes make precise identification of lesions related to tremor in MRI or autopsy impossible. The role of sparing dopaminergic pathways by the MS process and lack of improvement after l-dopa might be important but are still not clear in the pathophysiology of MS tremor. Frequent symmetrical, bilateral manifestation of tremor among MS patients might indicate more complex pathophysiological processes underlying the tremor. The mechanism of bilateral manifestation might be only partially explained by symmetrical changes observed in the cerebellum or thalamus [5,12-14,17-19].

Complex neurological symptoms in MS make description of the type of tremor difficult. Numerous techniques and rating scales have been used to evaluate MS tremor, but their reliability and validity have not been proven to be objective. Sophisticated tools and mathematical models created to analyse MS tremor have not been widely used, mostly because of their complexity and poor standardization [2-4]. The progressive character of the disease and risk of exacerbations influence evaluation of tremor and neurological syndrome, both before and after surgery $[1,2,4]$.

The increasing number of patients qualified for Vim DBS in numerous centres indicates that there is a high demand for treatment of MS-related tremor. Risk related to the surgery in this group of patients is relatively high. Long lasting, two-stage surgery that requires implantation of a foreign body might affect labile MS patients, where the immunological response plays an important role in the course of the disease [17-19]. We did not observe any MS relapses, but the risk of deterioration not directly related to the surgery (such as haematoma or infection) but to the relapse of MS should not be forgotten. Theoretically, higher risk of post-surgical infection among patients treated with immunosuppressants should be taken into account as well $[3,4,11,18]$. 


\section{Conclusions}

1. Medically refractory, disabling MS tremor can be effectively treated neurosurgically with thalamic deep brain stimulation or thalamotomy.

2. Even though Vim DBS carries a small risk of complications, the treatment should be restricted to patients severely disabled by tremor, in whom other neurological deficits do not significantly impair patients' quality of life.

3. A study on a larger group of patients and longer follow-up might result in a clear qualification protocol that would increase the efficacy of the treatment.

\section{Acknowledgement}

'Thalamic deep brain stimulation for tremor among multiple sclerosis patients' has been orally presented at the Scientific Conference of the Stereotactic and Functional Neurosurgery Section of the Polish Neurosurgical Association at Ustron, Poland on March 4-5, 2010.

\section{Disclosure}

The authors report no conflict of interest.

\section{References}

1. Geny C., Nguyen J.P., Pollin B., et al. Improvement of severe postural cerebellar tremor in multiple sclerosis by chronic thalamic stimulation. Mov Disord 1996; 11: 489-494.

2. Berk C., Carr J., Sinden M., et al. Thalamic deep brain stimulation for treatment of tremor due to multiple sclerosis: a prospective study of tremor and quality of life. $J$ Neurosurg 2002; 97: 815-820

3. Alusi S.H., Worthington J., Glickman S., et al. Evaluation of three different ways of assessing tremor in multiple sclerosis. J Neurol Neurosurg Psychiatry 2000; 68: 765-760.

4. Matsumoto J., Morrow D., Kaufmann K., et al. Surgical therapy for tremor in multiple sclerosis. An evaluation of outcome measures. Neurology 2001; 57: 1876-1882.

5. Alusi S.H., Glickman S., Aziz T.Z., et al. Tremor in multiple sclerosis. J Neurol Neurosurg Psychiatry 1999; 66: 131-134.

6. Berk C., Honey C.R. Bilateral thalamic deep brain stimulation for the treatment of head tremor. $J$ Neurosurg 2002; 96: 615-618.

7. Putzke J.D., Uitti R.J., Obwegeser A.A., et al. Bilateral thalamic deep brain stimulation: midline tremor. $J$ Neurol Neurosurg Psychiatry 2005; 76: 684-690.

8. Tronnier V., Fogel M., Krause M., et al. High frequency stimulation of the basal ganglia for the treatment of movement disorders: current status and medical results. Minim Invas Neurosurg 2002; 45: 91-96.
9. Benabid A.L., Pollak P., Dongming G., et al. Chronic electrical stimulation of ventralis intermedius nucleus of the thalamus as a treatment of movement disorders. J Neurosurg 1996; 84: 203-214.

10. Umemura A., Jaggi J.L., Hurtig H.I., et al. Deep brain stimulation for movement disorders: morbidity and mortality in 109 patients. J Neurosurg 2003; 98: 779-784.

11. Schurman P.R., Bosch D.A., Bossuyt P., et al. A comparison of continuous thalamic stimulation and thalamotomy for suppression of severe tremor. $N$ Engl J Med 2000; 342: 461-468.

12. Hore J., Wild B., Diener H.C. Cerebellar dysmetria at the elbow, wrist and fingers. J Neurophysiol 1991; 65: 563-571.

13. Sethi K.D. Tremor. Curr Opin Neurol 2003; 16: 481-485.

14. Diener H.C., Dichgans J. Pathophysiology of cerebellar ataxia. Mov Disord 1992; 7: 95-109.

15. Schwalb J., Lozano A. Surgical management of tremor. Neurosurg 2004; 14: 60-68.

16. Romanelli P., Bronte-Stewart H., Courtney T., et al. Possible necessity for deep brain stimulation of both the ventralis intermedius and subthalamic nuclei to resolve Holmes tremor. J Neurosurg 2003; 99: 566-571.

17. Pittock S.J., McClelland R.L., Mayer W.T., et al. Prevalence of tremor in multiple sclerosis and associated disability in the Olmsted County population. Mov Disord 2004; 19: 1482-1485.

18. Bittar R.G., Hyam J., Nandi D., et al. Thalamotomy versus thalamic stimulation for multiple sclerosis tremor. J Clin Neurosci 2005; 12: 638-642.

19. Timmermann L., Volkmann J. Deep brain stimulation for treatment of dystonia and tremor. Nervenarzt 2010; 81: 680-687.

20. Fahn S., Tolosa E., Marin C. Clinical rating scale for tremor. In: Jankovic J., Tolosa E. [eds.]. Parkinson's disease and movement disorders. Urban and Schwarzenberg, Baltimore 1988, pp. 225-234.

21. Brown R.G., MacCarthy B., Jahanshahi M., et al. Accuracy of self-reported disability in patients with parkinsonism. Arch Neurol 1989; 46: 955-959.

22. Bain P.G., Findley L.J., Thompson P.D., et al. A study of hereditary essential tremor. Brain 1994; 117: 805-824.

23. Guiot G., Derome P., Trigo J.C. Le tremblement d'attitude. Indication la meilleure de la chirurgie stéreotaxique. Presse Med 1967; 75: 2513-2518.

24. Guiot G., Arfel G., Derome P. La chirurgie stéreotaxique des tremblements de repos et d'attitude. Gaz Med France 1968; 75 : 4029-4056.

25. Guiot G., Derome P., Arfel G., et al. Electrophysiological recordings in stereotaxic thalamotomy for parkinsonism. Prog Neurol Surg 1973; 5: 189-221. 